\title{
Correlation of maternal age with placenta previa
}

\author{
Arul Anne Rose $\mathrm{S}^{1}$ and Ushadevi Gopalan ${ }^{2}$ \\ ${ }^{1}$ Dr. Arul Anne Rose S, Associate Professor, Department of Obstetrics and Gynaecology, ${ }^{2}$ Dr. Ushadevi Gopalan, \\ Associate Professor, Department of Obstetrics and Gynaecology. Both are affiliated to Tagore Medical College and \\ Hospital, Rathinamangalam, Chennai, INDIA.
}

Address for correspondence: Dr. Arul Anne Rose S, Associate Professor, Department of Obstetrics and Gynaecology, Tagore medical college and hospital, Rathinamangalam, Chennai, E-mail: annejoan04@gmail.com

\begin{abstract}
Objective: To study the effect of maternal age on incidence of placenta previa. Introduction: Placenta previa is a serious and life threatening obstetric complication where the placenta lies within the lower segment of the uterus, presenting an obstruction to the cervix and to delivery. A trend of increasing placenta previa incidence was observed in the past decade mainly because of an increasing caesarean section rate and advancing maternal age at the time of pregnancy. Methods: This study was a prospective study conducted in a teaching medical college and hospital over a period of three years [2011- 2014]. A detailed history was taken according to our proforma for all pregnant women at or after 32 weeks who attended the hospital in the study period. As per inclusion and exclusion criteria of our study, the study population was selected. All other risk factors for placenta previa except maternal age were excluded. The association between maternal age and placenta previa was analysed. Placenta was located by Transabdominal ultrasound and patients with placenta previa were followed up regularly. Results: Our study showed that women aged $\geq 35$ years or more had increased risk of placenta previa(3.6\%) which was statistically significant $(\mathrm{p}<0.05)$ by Chi-square test. Conclusion- Advancing maternal age ( $\geq 35$ years) appears to increase the risk of placenta previa independent of other risk factors.
\end{abstract}

Keywords: Maternal Age, Placenta Previa, Advanced Maternal Age.

\section{Introduction}

Placenta previa is a serious and life threatening obstetric complication where the placenta lies within the lower segment of the uterus, presenting an obstruction to the cervix and to delivery. Risk factors for placenta previa include advanced maternal age, gravidity of 3 or more, history of previous cesarean section, previous abortions etc [1]. It is one of the main causes of vaginal bleeding in the third trimester [2] and a significant cause of maternal $[3,4]$ and perinatal morbidity and mortality [5].

Advanced maternal age, defined as age 35 years or older at the date of delivery, has become more common. This age group is associated with subfertility, chromosomal abnormalities in offspring, multiple gestations and many obstetric risks including placenta previa [6].

Manuscript received: $14^{\text {th }}$ Aug 2015

Reviewed: $29^{\text {th }}$ Aug 2015

Author Corrected: $17^{\text {th }}$ Sept 2015

Accepted for Publication: $19^{\text {th }}$ Sept 2015

International Journal of Medical Research and Review
The incidence of placenta previa varies from $0.2 \%$ to $1.9 \%$ [7-10]. A trend of increasing placenta previa incidence was observed in the past decade mainly because of an increasing caesarean section rate[11] and advancing maternal age at the time of first pregnancy[12,13].The strongest connection was found between previous history of caesarean section[14-19], high parity [15,16,19] and advanced maternal age [20].

The aim of this study was to study the effect of maternal age on the incidence of placenta previa.

\section{Materials and Methods}

The study was conducted after getting permission from Institutional Ethical Committee and detailed informed consent was obtained from the patients. The study was a hospital based prospective study conducted in a teaching medical college and hospital for a period of 
three years (2011-2014). As per proforma, details were collected from all pregnant women at or after 32 weeks who attended the hospital in the study period.

\section{Exclusion Criteria-}

Multifetal gestation

Para 4 and above

Previous uterine surgeries

Previous placenta previa

Previous LSCS

\section{Results}

Total number of patients delivered in our hospital from July 2011 to June 2014 was 1992. Patients with known risk factors for placenta previa were excluded from the study [like multiple gestations, grand multi, previous LSCS, previous uterine curettage, uterine surgeries, previous placenta previa].

Table 1: Incidence of placenta previa in various maternal age groups

\begin{tabular}{|l|l|l|l|}
\hline Age (years) & No. of patients & Placenta previa & Incidence \\
\hline$\leq 19$ & 11 & 1 & $9.1 \%$ \\
\hline $20-24$ & 379 & 3 & $0.8 \%$ \\
\hline $25-29$ & 842 & 6 & $0.7 \%$ \\
\hline $30-34$ & 356 & 4 & $1.1 \%$ \\
\hline$\geq 35$ & 56 & 2 & $3.6 \%$ \\
\hline
\end{tabular}

Of the remaining 1644 patients (Table 1), patients with age $\leq 19$ years were 11 , of which one patient was diagnosed to have placenta previa.The incidence was $9.1 \%$. In the age group of 20-24 years there were 379 patients and 3 of them had placenta previa (incidence-0.8\%). In the age group of 25-29 years there were 842 patients and 6 of them had placenta previa (incidence-0.7\%). In the age group of 30-34 years there were 356 patients and 4 of them had placenta previa (incidence-1.1\%). In the age group of $\geq 35$ years there were 56 patients, 2 of them had placenta previa (incidence-3.6\%). The incidence of placenta previa in the age group $\geq 35$ years $(3.6 \%)$ when compared to other age groups was found to be high and it was statistically significant by Chi square test $(\mathrm{p}<0.05)$.

\section{Discussion}

Placenta previa can have very serious adverse effects for both mother and baby, including an increased risk of maternal and neonatal mortality [21-23], fetal growth restriction and preterm delivery [24], antenatal and intrapartum haemorrhage [3, 25,26] and women may require a blood transfusion [27]. A trend of increasing placenta previa incidence was observed in the past decade mainly because of an increasing caesarean section rate [11,15-19] and advancing maternal age[20] at the time of first pregnancy. The other risk factors which showed strong correlation with placenta previa include high parity $[15,16,19]$, history of previous abortions[11,16], previous uterine operations, previous placenta previa [28] and multiple gestations[29].

As per the exclusion criteria of our study all possible independent risk factors for placenta previa have been excluded. The incidence of placenta previa in patients with various age groups was calculated. Total number of patients delivered in our hospital during our study period was 1992. Of them 25 patients with multi fetal gestation were excluded from the study. Of this one patient had placenta previa making an incidence of $4 \%$. But the number of patients with twins was very less in our study making it not possible to comment on the significance. Strong et al [30] reported that the incidence of placenta previa was $0.55 \%$ for twin gestation as compared with $0.31 \%$ for singleton gestation.

Babinzki et al and Eniola et al $[31,32]$ showed that the incidence of previa was high $(2.2 \%)$ in women of para 5 or more when compared to women of lower parity. According to Laverty [33] placenta previa occurs in 
$0.2 \%$ of nulliparous women and up to $5 \%$ of grand multiparas; hence patients with para 4 and above (1patient) have been excluded from the study as per our exclusion criteria.

Those patients with previous endometrial damage and myomectomy scars (68 patients) have been excluded as Rose and Chapman [34] reported significant association between placenta previa and previous curettage. Monica et al [35] reported that women who have a history of placenta previa have an increased risk of placenta previa in subsequent pregnancy, hence we have excluded 2 patients with this history from the study. Silver and associates [36] cited an increased risk of previa in women who had prior caesarean delivery. The incidence was $1.3 \%$ for those with one prior cesarean delivery. Miller and associates [37] cited a threefold increased risk for placenta previa in women with a prior cesarean delivery. Hence patients with previous LSCS (252 patients) have been excluded from the study.

Of the remaining 1644 patients, patients with $\leq 19$ years were 11 , of which one patient was diagnosed to have placenta previa. The incidence was $9.1 \%$. Again since the numbers were very less (only 11 patients), we cannot really comment on the significance of this result. In the age group of 20-24 years there were 379 patients and 3 of them had placenta previa (incidence-0.8\%) in the age group of 25-29 years there were 842 patients and 6 of them had placenta previa (incidence-0.7\%). In the age group of 30-34 years there were 356 patients and 4 of them had placenta previa (incidence-1.1\%).In the age group of $\geq 35$ years there were 56 patients. 2 of them had placenta previa. (Incidence-3.6\%). The incidence of placenta previa in the age group $\geq 35$ years $(3.6 \%)$ when compared to other age groups was found to be high and it was statistically significant by Chi square test $(\mathrm{p}<0.05)$.

Advancing maternal age increases the risk of placenta previa. The incidence of previa increased significantly with each advancing maternal age group. It is 1 in 1500 for women 19 years or younger and is 1 in 100 for women older than 35. Increasing maternal age has caused an increased overall incidence of previa from $0.3 \%$ in 1976 to $0.7 \%$ in 1997[11]. In more than 36000 women enrolled in the FASTER TRIAL, those older than 35 years had a $1.1 \%$ risk for previa compared with that of $0.5 \%$ for women less than 35[6].

The relationship between incidence of placenta previa and maternal age has been established in many studies and our study also proved that. The mechanism by which advanced maternal age impairs normal placental development is still not well understood. One of the possible explanations could be that the percentage of sclerotic changes on intramyometrial arteries increases with increasing age, thereby reducing blood supply to placenta [20].

It is important to know about the risk factors which predispose women for placenta previa, so that we can take adequate preventive measures like avoiding pregnancies after 35 years of age. Physician should suspect placenta previa especially if woman is over 35 years and above, has had 3 or more previous pregnancies, increased number of previous abortions and cesarean sections[1]. These women should receive counselling as soon as pregnancy is confirmed. It is especially important in non compliant pregnant women with possible poor antenatal care. Very careful monitoring of these patients is of utmost importance, especially ultrasonographic examination with proper placental location during second trimester of pregnancy. Early identification and appropriate care for placenta previa cases will prevent all potential dangerous complications for mother and fetus.

\section{Conclusion}

The risk of placenta previa is increased with increasing maternal age. Placenta previa in turn increases the risk of complications like obstetrical haemorrhage and the need for caesarean hysterectomy. To prevent the deadly complications of placenta previa, all pregnant women with high risk factors like advanced maternal age should undergo at least one ultrasound examination during second trimester of pregnancy.

\section{Funding: Nil \\ Conflict of interest: None. \\ Permission of IRB: Yes}

\section{References}

1. Tuzoviae et al: Obstetric Risk Factors and Placenta Previa. Croat Med J 2003; 44:728-733.

2. Cunningham FG, Gant NF, Leveno KL, Gilstrap III LC, Hauth JC, Wenstrom KD. Williams Obstetrics. 21st Ed. New York (NY): Mc Graw Hill; 2001 
3. Crane JMG, Van den Hof MC, Dodds L, Armson BA, Liston R. Maternal complications with placenta previa. Am J Perinatol 2000; 17(2): 101-5

4. Love CD, Wallace EM. Pregnancies complicated by placenta previa: what is appropriate management? $\mathrm{Br} \mathbf{J}$ Obstet Gynaecol 1996 Sep; 103(9):864-7

5. Crane JMG, Van den Hof MC, Dodds L, Armson BA, Liston R. Neonatal outcomes with placenta previa. Obstet Gynecol 1999 Apr; 93(4):541-4

6. Cleary -Goldman J, Malone FD, Vidaver $\mathrm{J}$ et al: Impact of maternal age on obstetric outcome. Obstet Gynecol 2005; 105:983-90

7. Gallagher P, Fagan CJ, Bedi DG, Winsett MZ, Reyes RN. Potential placenta previa: definition, frequency and significance. Am J Roentgenol. 1987 Nov; 149(5): 1013-5

8. Anderson ES, Steinke NMS. The clinical significance of asymptomatic mid-trimester low placentation diagnosed by ultrasound. Acta Obstet Gynecol Scand 1988; 67(4): 339-41

9.Taipale P, Hiilesman V, Ylostalo P. Transvaginal ultrasonography at 18- 23 weeks in predicting placenta previa at delivery. Ultrasound Obstet Gynecol. 1998 Dec; 12(6):422-5

10. Mustafe SA, Brizot ML, Carvelho MHB, Watanabe L, Kahhale S, Zugaib M. Transvaginal ultrasonography in predicting placenta previa at delivery: a longitudinal study. Ultrasound Obstet Gynecol. 2002 Oct; 20(4): 356-9.

11. Ananth CV, Smulian JC, Vintzielos A. The association of placenta previa with history of cesarean delivery and abortion: a Meta analysis. Am J Obstet Gynecol 1997 Nov; 177(5): 1071-8

12. Frederiksen MC, Glassenberg R, Stika C. Placenta previa: a 22- year analysis. Am J Obstet Gynecol 1999; 180(6pt1): 1432-7

13. Ziadeh S, Yahaya A. Pregnancy outcome at age 40 and older. Arch Gynecol Obstet 2001 Mar; 265(1): 30-3

14. Sheiner E, Shoham- Vardi I, Hallak M, Hershkowitz R, Katz M, Mazor M. Placenta previa: obstetric risk factors and pregnancy outcome. J Matern Fetal Med 2001 Dec; 10(6): 414-9

15. Parazzini F, Dindelli M, Luchini L, La Rosa M, Potenza MT, Frigerio L, et al. Risk factors for placenta previa. Placenta 1994 Apr; 15(3):321-6

16. Abu-Heija A, El-Jallad F, Ziadeh S. Placenta previa: effect of age, gravidity, parity and previous cesarean section. Gynecol Obstet Invest 1999; 47(1):6-8

17. Hershkowitz R, Fraser D, Mazor M, Leiberman JR. One or multiple previous cesarean sections are associated with similar increased frequency of placenta previa. Eur J Obstet Gynecol Reprod Biol 1995; 62:185-8.

18. Hendricks MS, Chow YH, Bhagavath B, Singh K. Previous cesarean section and abortion as risk factors for developing placenta previa. J Obstet Gynaecol Res 1999 Apr; 25(2):137-42.

19. Gilliam M, Rosenberg D, Davis F. The likelihood of placenta previa with greater number of cesarean deliveries and higher parity. Obstet Gynecol 2002; 99:976-80

20. Zhang J, Savitz DA. Maternal age and placenta previa: a population -based, case- control study. Am J Obstet Gynecol 1993; 168:641-5

21. Salihu HM, Li Q, and Rouse DJ, Alexander GR: Placenta previa: Neonatal death after live births in the United States. Am J Obstet Gynecol 2003; 188(5): 1305-9

22. Ananth CV, Smulian JC, Vintzileos AM. The effect of placenta previa on neonatal mortality: a population based study in the United States, 1989 through 1997. Am J Obstet Gynecol 2003; 188(5): 1299-1304

23. Iyasu S, Saftlas AK, Rowley DL, Koonin LM, Lawson HW, Atrash HK: The Epidemiology of Placenta previa in the United States, 1979 through 1987. Am J Obstet Gynecol 1993 May; 168(5): 1424-9

24. Ananth CV, Demissie K, and Smulian JC, Vintzileos AM: Relationship among placenta previa, fetal growth restriction and preterm delivery: A population based study. Obstet Gynecol Aug 2001; 98(2):299-306 
25. Brace V, Kemaghan D, and Penney G: Learning from adverse clinical outcomes: major obstetric haemorrhage in Scotland, 2003-05. BJOG 2007; 114(11):1388-1396

26. Bhide A, Prefumo F, Moore J, Hollis B, Thilaganathan B: Placental edge to internal os distance in the late third trimester and mode of delivery in placenta previa. BJOG 2003, 110(9):860-864

27. Lydon -Rochelle M, Holt VL, Easterling TR, and Martin DP: First - birth cesarean and placental abruption or previa at second birth. Obstet Gynecol 2001; 97(5):765-769

28. Gorodeski IG, Bahari CM. The effect of placenta previa localization upon maternal and fetal - neonatal outcome. J Perinat Med 1987; 15(2):169-77

29. Francois K, Johnson JM, Harris C. Is placenta previa more common in multiple gestations? Am $\mathbf{J}$ Obstet Gynecol 2003 May; 188(5): 1226-7

30. Strong T, Brar H. Placenta previa in twin gestations. J Reprod med. 1989 Jun; 34(6):415-6

31. Babinszki A, Kerenyi T, Torok O, Grazi V, Lapinski RH, Berkowitz RL. Perinatal outcome in grand and great grand multiparity: effects of parity on obstetric risk factors. Am J Obstet Gynecol 1999(Sep); 181(3):669-74

32. Eniola AO, Bako AU, Selo -Ojeme DO. Risk factors for placenta previa in Southern Nigeria. East Afr Med J.2002 Oct; 79(10):535-8

33. Laverty PL. Placenta previa. Clin Obstet Gynecol. 1990 Sep; 33(3):414-21

34. Rose GL, Chapman MG. Aetiological factors in placenta previa- a case controlled study. $\mathrm{Br} \mathrm{J}$ Obstet Gynaecol. 1986 Jun; 93(6): 586-8

35. Monica G, Lilja C. Placenta previa, maternal smoking and recurrence risk. Acta Obstet Gynaecol Scand. 1995 May; 74(5): 341-5

36. Silver RM, Landon MB, Rouse DJ et al: Maternal morbidity associated with multiple repeat cesarean deliveries. Obstet Gynecol 2006 Jun; 107(6):1226-32

37. Miller DA, Diaz FG, Paul RH: Incidence of placenta previa with previous cesarean. Am J Obstet Gynecol 1996; 174:345.

\section{How to cite this article?}

Arul Anne Rose S, Ushadevi Gopalan. Correlation of maternal age with placenta previa. Int J Med Res Rev 2015;3(9):914-918. doi: 10.17511/ijmrr.2015.i9.171. 